\title{
Subchronic toxicity of the beverage made from Cassia occidentalis seeds in mice
}

\author{
Véronique Josette Essa'a*, Gabriel Nama Medoua \\ Centre for Food and Nutrition Research, IMPM, Yaoundé, Cameroon
}

\section{Email address:}

veroessaa@yahoo.fr (V. J. Essa'a)

\section{To cite this article:}

Véronique Josette Essa'a, Gabriel Nama Medoua. Subchronic Toxicity of the Beverage Made from Cassia Occidentalis Seeds in Mice. International Journal of Nutrition and Food Sciences. Vol. 2, No. 5, 2013, pp. 237-242. doi: 10.11648/j.ijnfs.20130205.14

\begin{abstract}
Cassia occidentalis seeds are commonly used in West of Africa to prepare a beverage which serves as a substitute for coffee, however these seeds are known to be toxic. A 20-day subchronic oral toxicity of $C$. occidentalis seeds and beverage was evaluated in male and female albino mice. Raw or roasted seeds of $C$. occidentalis were administered in the diet of one group of mice at dose levels of 0 and $100 \mathrm{~g} / \mathrm{kg}$ /day for 20 days, while $1 \mathrm{ml}$ of water or of beverage prepared from raw or roasted seeds was administered two-time daily to another group. The addition of raw seeds to the diet had significant $(\mathrm{p} \leq 0.05)$ effects with clinical signs attributable to the test compound including weight body loss, increase of liver enzymes (GOT and GPT) activity and serum ammonia level, decrease of serum protein level and increase of Hepato-somatic-index. Addition of roasted seeds in the diet or administration of beverages prepared from the seeds had no clinical signs attributable to the test compound. These findings indicate that roasting and extraction, the two key operations in the process of $C$. occidentalis beverage, eliminate the toxicity of the seeds. It is suggested that roasting destroys the toxin and water which is used as solvent during the infusion is inefficient to extract the toxin from the grounded seeds.
\end{abstract}

Keywords: Cassia occidentalis, Beverage, Roasting, Toxicity

\section{Introduction}

Roots, leaves, flowers and seeds of Cassia occidentalis are widely used in traditional medicine throughout the world [1,2-4,5]. In West of Africa, C. occidentalis seeds are commonly roasted and infused in a coffee-like beverage $[5,6]$. However, several studies show that $C$. occidentalis seeds are toxic; they are responsible of a syndrome characterised by generalised muscles degeneration [7,8-11,12]. The fact that beverage made by $C$. occidentalis seeds is widely consumed by populations of several West African countries, conducts to a paradoxical situation, which raises questions about innocuousness of this beverage. Seeds roasting and extraction of soluble solids into an aqueous infusion are the two key operations in the process of $C$. occidentalis beverage preparation [13].

Suliman et al. reported a partial reduction of $C$. occidentalis seeds toxicity after roasting, both Hebert et al. and Graziano et al. reported that if aqueous solvents can extract toxin from the seeds, they cannot make it soluble in the extract [14-16]. However, to the best of our knowledge, no study has so far evaluated the toxicological risk linked to the consumption of the beverage prepared from $C$. occidentalis seeds. The present study was therefore carried out with the aim at determining the toxicological changes occurring during the processing of $C$. occidentalis seeds into beverage.

\section{Materials and Methods}

\subsection{Plant Materials}

Cassia occidentalis L. (syn. Senna occidentalis; Leguminosae) seeds were randomly harvested at physiological maturity from several plants in different areas of Ngaoundéré in the Adamawa Region of Cameroon. The plant materials were processed the day they had been harvested. Healthy seeds were removed from the cloves, thoroughly washed with water, dried at $40^{\circ} \mathrm{C}$ in a ventilated oven during $24 \mathrm{~h}$ and stored in a watertight container.

\subsection{Animals}

Fifty male and 50 female albino mice (Muscus maculatus var albino) and their diet were bought at 6 weeks of age at the National Veterinary Laboratory (Garoua, Cameroon). At such, the use of animals was in accordance with $\mathrm{NIH}$ 
recommendations [17]. Tail tattoos were used to identify each animal individually. The animals were acclimated to the laboratory for 1 week before the beginning of the experiment. During the acclimation period, the animals were observed daily for signs of illness. The body weights at the beginning of the test ranged from $20 \mathrm{~g}$ to $24 \mathrm{~g}$.

The animals were housed in group of five (5 animals/cage/sex) in clear polycarbonate cages. Sterilised soft wood chips were used as bedding; they were changed every three days. Animals were assigned to different cages by means of randomisation, stratified by body weight so that the mean body weights in cages were homogeneous by statistical analysis. Diet and tap water were provided ad libitum. Both feed and water consumption were measured daily. The temperature maintained throughout the study was $20^{\circ} \mathrm{C}-26^{\circ} \mathrm{C}$ with relative humidity of $60-80 \%$. The photoperiod was a $12 \mathrm{~h}$ light/dark cycle.

\subsection{Group Assignment}

Animals were assigned to 2 groups composed of 3 dose subgroups each; the first group in order to evaluate the effect of roasting and in the second one, to evaluate the effect of extraction. Five animals of each sex were assigned to each of the 6 subgroups. A third group of 10 animals of each sex was identified as the baseline data group. Allocation was accomplished using a stratified weight randomization method.

Animals of the two test groups were treated as described below:

a) Group1:

- Subgroup1: Control1; animals receiving no seeds of C. occidentalis,

- Subgroup2: Test1; animals receiving raw seeds of $C$. occidentalis,

- Subgroup3: Test2; animals receiving roasted seeds of $C$. occidentalis.

b) Group2. The dose was administered by oral gavages two times per day, in the morning by 8 am and in the afternoon by $6 \mathrm{pm}$ as follows:

- Subgroup4: Control2; animals receiving $1 \mathrm{ml}$ of water,

- Subgroup5: Test3; animals receiving $1 \mathrm{ml}$ of the beverage prepared with raw seeds of $C$. occidentalis,

- Subgroup6: Test4; animals receiving $1 \mathrm{ml}$ of the beverage prepared with roasted seeds of $C$. occidentalis.

\subsection{Dose Levels and Diet Preparation}

For the first group of animals, $C$. occidentalis seeds were roasted at $200^{\circ} \mathrm{C}$ for 0 or $10 \mathrm{~min}$, grounded into flour to pass through $300 \mu \mathrm{m}$ sieve and incorporated in diet at the level of $10 \%$. Appropriate amounts of seeds flour and meal were blended together for at least $15 \mathrm{~min}$.

For animals of the second group, C. occidentalis seeds were roasted at $200^{\circ} \mathrm{C}$ for 0 or $10 \mathrm{~min}$, grounded to pass through $300 \mu \mathrm{m}$ sieve and $5 \mathrm{~g}$ of grounded seeds infused in
$150 \mathrm{ml}$ of boiling water for $10 \mathrm{~min}$ [13]. Each $\mathrm{ml}$ of the resulting extract was equivalent to about $13.7 \mathrm{mg}$ of soluble solids. $1 \mathrm{ml}$ of infusion was administered to animals two times daily, representing about $1.25 \mathrm{mg}$ of soluble solids/g of body weight/day. This dose corresponds to the average human consumption of $C$. occidentalis beverage.

\subsection{Test Procedures}

The test had been conducted in 20 days, during which, mice body weight were measured every 2 days, starting from day2 for animals of Group1 and day 6 for animals of Group2. The number of death was recorded during the experiment. Both food consumption and water consumption were measured on a daily basis.

The last day of the experiment, all animals were anesthetized using sodium pentobarbital and blood was collected from the right ventricle into plain tubes for biochemical analysis. The blood collected was centrifuged at $2000 \mathrm{~g}$ for $10 \mathrm{~min}$ in order to obtain the serum, which was analyzed for ammonia, glutamate oxaloacetate transaminase (GOT) and glutamate pyruvate transaminase (GPT) by standard ready-to-use kits (Human Gesellschaft für Biochemica and Diagnostica MBH, Germany). Protein content was determined using Bradford method with bovine serum albumin $\mathrm{V}$ as the standard [18]. Thereafter, the animals were sacrificed and the whole liver removed and weighted for evaluation of Hepato-Somatic Index (HSI $=$ liver weight $/$ body weight $\times 100$ ).

\subsection{Statistical Analysis}

Statistical analyses were performed using SPSS Statistics 10.0 software (SPSS Inc., Chicago, IL, USA). Results were expressed as mean \pm SD. First type error risk was set at 0.05 for all analyses. Comparisons between dependent variables were determined using analysis of variance, Dunnett's T3 test or Student's t-test.

\section{Results and Discussion}

\subsection{Food and Water Consumption}

Table1 displays the daily food and water consumption of animals in the different groups. Analysis of variance showed no significant $(\mathrm{P} \leq 0.05)$ treatment-related effect in water and food consumption for mice of group2 (receiving beverage prepared from $C$. occidentalis raw or roasted seeds). The same analysis showed no significant treatment-related effect in water consumption for animals of group1 (receiving raw or roasted seeds of $C$. occidentalis), and a significant effect in food consumption. Food consumption was significantly $(\mathrm{P} \leq 0.05)$ higher in the subgroup receiving roasted seeds compared to the control and the subgroup receiving raw seeds. This result suggested that $C$. occidentalis roasted seeds stimulate the appetite of mice while crude seeds decrease it. 


\subsection{Body Weight and Mortality}

\subsubsection{Case of Animals of Group1 Receiving Commercial Diet Contaminated with Raw or Roasted Seeds}

Figure 1 presents the variation of body weight for animals of each subgroup. Significant $(\mathrm{P} \leq 0.05)$ treatment-related effects were observed in mice body weights. Body weight of mice receiving roasted $C$. occidentalis seeds significantly increased compare to the control, while those receiving raw seeds showed a significant decrease of body weight.

It was suggested that the decrease of body weight noted in animals receiving raw seeds is a manifestation of seeds toxicity. This is in agreement with previous studies [7,8-11,12] reporting body weight decreased amount intoxication signs of $C$. occidentalis seeds. This hypothesis was comforted in the present study by the $60 \%$ of death noted for animals receiving raw seeds (Figure1). No death was observed in other subgroup. Male appeared to be more affected by seeds toxicity than female. In the mortality level obtained, $80 \%$ was recorded for male and only $40 \%$ for female. This result was explained by the moderate food consumption observed with female. In fact, female of the subgroup receiving raw seeds ingested $47 \%$ less food than male and therefore ingested less toxic compound than male.

The body weight increase observed in mice receiving roasted seeds suggested that the toxicity of $C$. occidentalis seeds was eliminated by the roasting process. This result is comparable to the one obtained by Suliman and Shommein who reported a partial reduction of $C$. occidentalis seeds toxicity after roasting [14]. In spite of the light difference observed between our result and the one reported by the said authors, differences which are besides can be explained by differences in roasting scale, the result obtained in this study confirms the one reported by Suliman and Shommein and suggests that the toxin in $C$. occidentalis seeds is a thermolabile compound [14].

The higher body weight increase observed in mice receiving roasted seeds compared to the control, was explained by the higher food consumption noted in that subgroup (Table1). Table2 presenting the effect of treatments on food efficacy defined as the ratio between weight gain and food consumption showed a significant increase of food efficacy with the incorporation of roasted seeds in the diet, suggesting that $C$. occidentalis roasted seeds bring a growing factor to the commercial diet.

\subsubsection{Case of Animals of Group2 Receiving Beverage Prepared from Raw or Roasted Seeds}

Figure 2 displays the variation of body weight for animals of each subgroup. No significant $(\mathrm{P} \leq 0.05)$ treatment-related effects were observed in mice body weights. All animals of the group presented a good increase of body weight. This result was in phase with the non significant $(\mathrm{P} \leq 0.05)$ effect of treatment obtained for food efficacy in this group (Table2).

\subsection{Biochemical and Somatic Analyses}

\subsubsection{Case of Animals of Group1 Receiving Commercial Diet Contaminated with Raw or Roasted Seeds}

Figure 3 displays variation in the levels of proteins, ammonia, tansaminases (GOT and GPT) in the serum, and Hepato-Somatic Index (HSI) for each subgroup of mice. Animals receiving $C$. occidentalis raw seeds showed decrease in proteins level and increase in ammonia level, liver enzymes (GOT and GPT) activities and HSI. All parameters of control and animals receiving roasted seeds remained stable (Table3). These results indicated that animals receiving raw seeds of $C$. occidentalis were intoxicated. Results obtained in this study are comparable to those of previous studies $[14,19]$ reporting that the toxin of $C$. occidentalis causes damages in liver, heart and lungs, damages which are manifested in the biochemical level by an increase of transaminases activity and serum level in ammonia, as well as a decrease of serum level in protein. These studies also reported an increase of total lipid in the liver, which could be explained here by the increase of HIS of intoxicated mice. The results obtained here combined with those obtained for body weight and mortality clearly indicated that toxicity of $C$. occidentalis seeds is eliminated by seeds roasting at $200^{\circ} \mathrm{C}$ for $10 \mathrm{~min}$.

\subsubsection{Case of Animals of Group2 Receiving Beverage Prepared from Raw or Roasted Seeds.}

No significant $(\mathrm{P} \leq 0.05)$ treatment-related effects were observed in animals' biochemical and somatic parameters (Figure4 and Table4). This suggested that the beverage prepared from $C$. occidentalis seeds do not present any toxicological risk. If the absence of toxicity in the beverage prepared from roasted seeds can be easily explained by the elimination of seeds toxicity during the roasting process, its absence in the beverage prepared from raw seeds is less evident. The toxin of $C$. occidentalis seeds being probably a thermolabile compound, a part of it may be eliminated during infusing $\left(95^{\circ} \mathrm{C}\right.$ for $\left.10 \mathrm{~min}\right)$. Graziano et al. reported a reduction of $C$. occidentalis toxic activity after heating at $90^{\circ} \mathrm{C}$ for $40 \mathrm{~min}$ [15]. However, the absence of intoxication signs in mice receiving beverage prepared from raw seeds could also be explained by the absence of toxin in the extract. This hypothesis is in phase with the conclusions of Hebert et al. who reported that if aqueous solvents are able to extract $C$. Occidentalis toxin from the seeds, this toxin is not dissolved in extract, it remains linked to particles of rafinate [16]. 


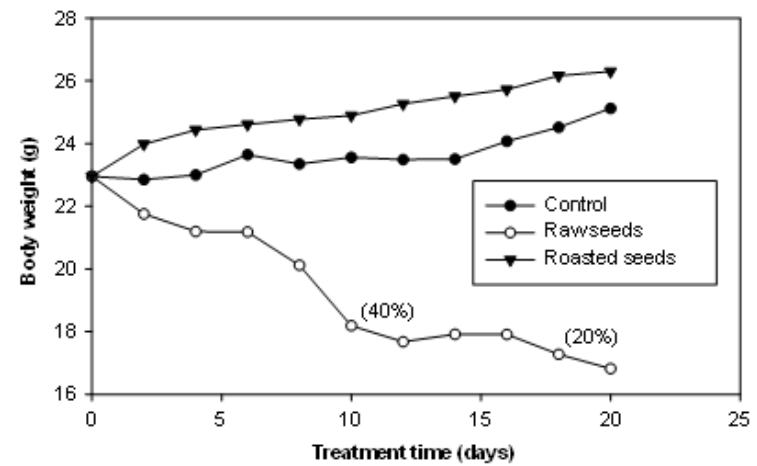

The percentage of mortality is indicated in the bracket near the point where it was observed

Figure1. Mortality and body weight evolution of animals receiving $10 \% \mathrm{C}$. occidentalis seeds in the commercial diet.

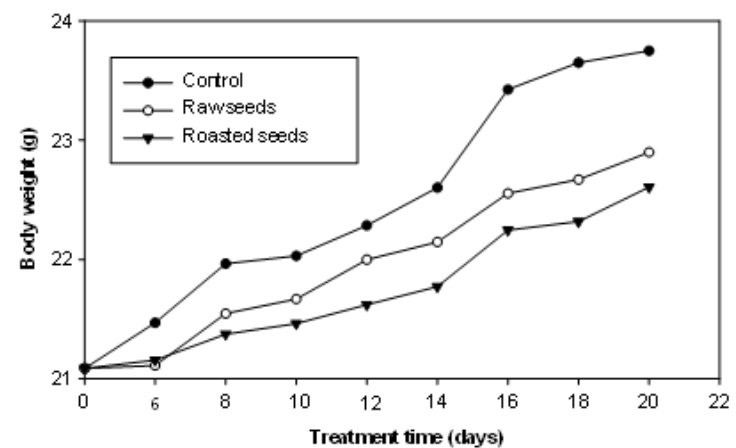

Figure2. Body weight evolution of mice receiving beverage prepared from C. occidentalis seeds.

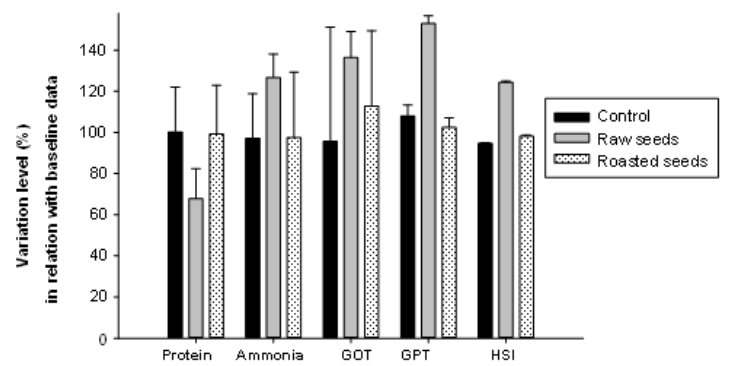

Figure3. Biochemical and somatic parameters of animals of group 1 receiving $10 \%$ C. occidentalis seeds in the commercial diet

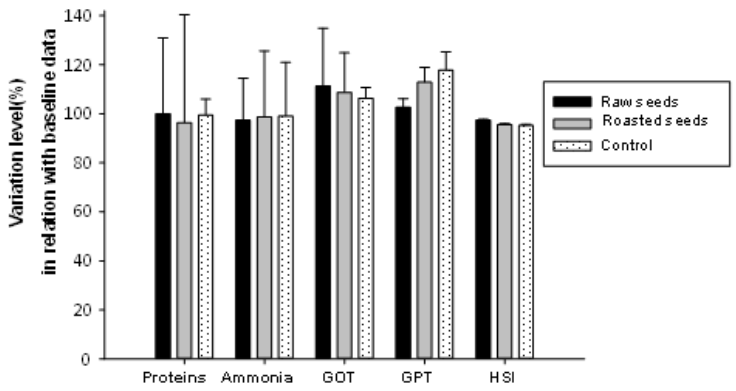

Figure4. Biochemical and somatic parameters of animals of group 2 receiving beverage prepared from raw or roasted seeds
Table1. Daily food and water consumption of mice in different groups

\begin{tabular}{ccc}
\hline Group & $\begin{array}{c}\text { Food (mg/g of mice } \\
\text { weight/day) }\end{array}$ & $\begin{array}{c}\text { Water (ml/mg of food } \\
\text { intake/day) }\end{array}$ \\
\hline Group1 (seeds) & $140 \pm 30^{\mathrm{a}}$ & $50 \pm 10^{\mathrm{a}}$ \\
Control1 & $120 \pm 80^{\mathrm{a}}$ & $70 \pm 50^{\mathrm{a}}$ \\
Test1 (raw seeds) & $170 \pm 50^{\mathrm{b}}$ & $60 \pm 20^{\mathrm{a}}$ \\
$\begin{array}{c}\text { Test2 (roasted } \\
\text { seeds) } \\
\text { Group2 } \\
\text { (beverage) }\end{array}$ & $150 \pm 70^{\mathrm{a}}$ & \\
$\begin{array}{c}\text { Control2 } \\
\text { Test3 (raw seeds) }\end{array}$ & $140 \pm 90^{\mathrm{a}}$ & $60 \pm 30^{\mathrm{a}}$ \\
$\begin{array}{c}\text { Test4 (roasted } \\
\text { seeds) }\end{array}$ & $120 \pm 30^{\mathrm{a}}$ & $60 \pm 30^{\mathrm{a}}$ \\
\hline
\end{tabular}

Mean $\pm \mathrm{SD}, \mathrm{n}=10$

Group $1=$ Mice receiving commercial diet contaminated with $10 \%$ raw or roasted seeds of $C$. occidentalis.

Group 2 = Mice receiving by gavage, $1 \mathrm{ml}$ of beverage prepared from raw or roasted seeds of $C$. occidentalis two times per days.

${ }^{a-b}$ Means in the same column, for each group, not sharing a common superscript are significantly different $(\mathrm{P}<0.05)$ according to Dunnett's T3 test.

Table2. Effect of mice treatments on food efficacy

\begin{tabular}{|c|c|}
\hline Group & $\begin{array}{l}\text { Food efficacy (weight gain/food intake } \\
\times 100)\end{array}$ \\
\hline \multicolumn{2}{|l|}{ Group1 (effect of roasting) } \\
\hline Control1 & $9.87 \pm 2.26^{\mathrm{a}}$ \\
\hline Test1 (raw seeds) & $-11.24 \pm 2.15^{\mathrm{b}}$ \\
\hline Test2 (roasted seeds) & $12.11 \pm 3.16^{\mathrm{c}}$ \\
\hline \multicolumn{2}{|l|}{ Group2 (effect beverage) } \\
\hline Control2 & $4.57 \pm 1.88^{\mathrm{a}}$ \\
\hline Test3 (raw seeds) & $4.33 \pm 1.32^{\mathrm{a}}$ \\
\hline Test4 (roasted seeds) & $4.36 \pm 1.54^{\mathrm{a}}$ \\
\hline
\end{tabular}

Mean $\pm \mathrm{SD}, \mathrm{n}=10$

Group $1=$ Mice receiving commercial diet contaminated with $10 \%$ raw or roasted seeds of $C$. occidentalis.

Group 2 = Mice receiving by gavage, $1 \mathrm{ml}$ of beverage prepared from raw or roasted seeds of $C$. occidentalis two times per days.

a-cMeans in the same column, for each group, not sharing a common superscript are significantly different $(\mathrm{P}<0.05)$ according to Dunnett's T3 test. 
Table3. Influence of treatment on some biochemical and somatic parameters of animals of group1 measuring the effect of roasting.

\begin{tabular}{|c|c|c|c|c|}
\hline \multirow{4}{*}{ Ammonia (mmole/ml of serum) } & Baseline & $549.5 \pm 12.4$ & & \\
\hline & Control & $534.3 \pm 21.6$ & baseline $v s$ control & $1.93^{\mathrm{ns}}$ \\
\hline & Test1 (raw) & $696.8 \pm 11.2$ & baseline $v s$ test 1 & $-73.6^{*}$ \\
\hline & $\begin{array}{c}\text { Test2 } \\
\text { (roasted) }\end{array}$ & $536.2 \pm 31.7$ & baseline $v s$ test 2 & $1.25^{\mathrm{ns}}$ \\
\hline \multirow{4}{*}{ Proteins (mg/ml de serum) } & Baseline & $303.7 \pm 8.2$ & & \\
\hline & Control & $304.6 \pm 21.7$ & baseline $v s$ control & $-0.12^{\mathrm{ns}}$ \\
\hline & Test1 (raw) & $206.3 \pm 14.4$ & baseline $v s$ test 1 & $27.95^{*}$ \\
\hline & $\begin{array}{c}\text { Test2 } \\
\text { (roasted) }\end{array}$ & $301.7 \pm 23.6$ & baseline $v s$ test 2 & $0.23^{\mathrm{ns}}$ \\
\hline \multirow{4}{*}{ GOT (U/I at $\left.37^{\circ} \mathrm{C}\right)$} & Baseline & $289.8 \pm 18.7$ & & \\
\hline & Control & $306.2 \pm 20.1$ & baseline $v s$ control & $0.33^{\mathrm{ns}}$ \\
\hline & Test1 (raw) & $378.7 \pm 12.5$ & baseline $v s$ test 1 & $-8.93 *$ \\
\hline & $\begin{array}{c}\text { Test } 2 \\
\text { roasted) }\end{array}$ & $310.5 \pm 19.6$ & baseline $v s$ test 2 & $-1.03^{\mathrm{ns}}$ \\
\hline \multirow{4}{*}{ GPT $\left(\mathrm{U} / \mathrm{l}\right.$ at $\left.37^{\circ} \mathrm{C}\right)$} & Baseline & $30.1 \pm 4.8$ & & \\
\hline & Control & $32.5 \pm 5.2$ & baseline $v s$ control & $-0.59^{\mathrm{ns}}$ \\
\hline & Test1 (raw) & $46.1 \pm 3.5$ & baseline $v s$ test1 & $-4.04 *$ \\
\hline & $\begin{array}{c}\text { Test2 } \\
\text { (roasted) }\end{array}$ & $30.8 \pm 4.5$ & baseline $v s$ test 2 & $-0.17^{\mathrm{ns}}$ \\
\hline \multirow{4}{*}{ HSI (\%) } & Baseline & $4.4 \pm 0.3$ & & \\
\hline & Control & $4.2 \pm 0.3$ & baseline $v s$ control & $1.75^{\mathrm{ns}}$ \\
\hline & Test1 (raw) & $5.5 \pm 0.4$ & baseline $v s$ test 1 & $-6.54 *$ \\
\hline & $\begin{array}{c}\text { Test2 } \\
\text { (roasted) }\end{array}$ & $4.3 \pm 0.3$ & baseline $v s$ test 2 & $0.56^{\mathrm{ns}}$ \\
\hline
\end{tabular}

Mean $\pm \mathrm{SD}, \mathrm{n}=10$

*significant at $\mathrm{P} \leq 0.05 ; \mathrm{ns}=$ non significant, according to Student's t test

Table4. Influence of treatments on some biochemical and somatic parameters of animals of group 2 measuring the extraction of toxin in the beverage.

\begin{tabular}{|c|c|c|c|c|}
\hline \multirow{4}{*}{$\begin{array}{c}\text { Ammonia } \\
\text { (mmole/ml of serum) }\end{array}$} & Baseline & $549.5 \pm 12.4$ & \multirow{3}{*}{$\begin{array}{c}\text { baseline } v s \text { control } \\
\text { baseline } v s \text { test } 3\end{array}$} & \multirow{3}{*}{$\begin{array}{l}0.55^{\mathrm{ns}} \\
2.14^{\mathrm{ns}}\end{array}$} \\
\hline & Control & $545.1 \pm 21.7$ & & \\
\hline & Test3 (raw) & $535.7 \pm 17.0$ & & \\
\hline & $\begin{array}{c}\text { Test4 } \\
\text { (roasted) }\end{array}$ & $542.8 \pm 26.8$ & baseline $v s$ test 4 & $0.76^{\mathrm{ns}}$ \\
\hline \multirow{4}{*}{$\begin{array}{c}\text { Proteins } \\
\text { (mg/ml of serum) }\end{array}$} & Baseline & $303.7 \pm 8.2$ & \multirow{4}{*}{$\begin{array}{l}\text { baseline } v s \text { control } \\
\text { baseline } v s \text { test } 3 \\
\text { baseline } v s \text { test } 4\end{array}$} & \\
\hline & Control & $302.2 \pm 6.4$ & & $0.49^{\text {ns }}$ \\
\hline & Test3 (raw) & $304.2 \pm 30.7$ & & $-0.04^{\mathrm{ns}}$ \\
\hline & $\begin{array}{c}\text { Test4 } \\
\text { (roasted) }\end{array}$ & $293.0 \pm 43.8$ & & $0.73^{\mathrm{ns}}$ \\
\hline \multirow{4}{*}{ GOT $\left(\mathrm{U} / \mathrm{I}\right.$ at $\left.37^{\circ} \mathrm{C}\right)$} & Baseline & $289.8 \pm 18.7$ & \multirow{4}{*}{$\begin{array}{c}\text { baseline } v s \text { control } \\
\text { baseline } v s \text { test } 3 \\
\text { baseline } v s \text { test } 4\end{array}$} & \\
\hline & Control & $295.5 \pm 4.2$ & & $-1.05^{\mathrm{ns}}$ \\
\hline & Test 3 (raw) & $309.2 \pm 23.4$ & & $-1.89^{\text {ns }}$ \\
\hline & $\begin{array}{l}\text { Test4 } \\
\text { (roasted) }\end{array}$ & $302.0 \pm 16.0$ & & $-1.84^{\mathrm{ns}}$ \\
\hline \multirow{4}{*}{ GPT $\left(\mathrm{U} / \mathrm{l}\right.$ at $\left.37^{\circ} \mathrm{C}\right)$} & Baseline & $30.1 \pm 4.8$ & \multirow{4}{*}{$\begin{array}{c}\text { baseline } v s \text { control } \\
\text { baseline } v s \text { test } 3 \\
\text { baseline } v s \text { test } 4\end{array}$} & \\
\hline & Control & $35.4 \pm 7.3$ & & $-1.12^{\mathrm{ns}}$ \\
\hline & Test3 (raw) & $30.9 \pm 3.4$ & & $-0.28^{\mathrm{ns}}$ \\
\hline & $\begin{array}{c}\text { Test4 } \\
\text { (roasted) }\end{array}$ & $34.0 \pm 5.9$ & & $-0.96^{\mathrm{ns}}$ \\
\hline \multirow{4}{*}{ IHS (\%) } & Baseline & $4.4 \pm 0.3$ & \multirow{4}{*}{$\begin{array}{l}\text { baseline } v s \text { control } \\
\text { baseline } v s \text { test } 3 \\
\text { baseline } v s \text { test } 4\end{array}$} & \\
\hline & Control & $4.2 \pm 0.3$ & & $1.39^{\mathrm{ns}}$ \\
\hline & Test3 (raw) & $4.3 \pm 0.1$ & & $0.90^{\text {ns }}$ \\
\hline & $\begin{array}{c}\text { Test4 } \\
\text { (roasted) }\end{array}$ & $4.2 \pm 0.4$ & & $1.35^{\mathrm{ns}}$ \\
\hline
\end{tabular}

Mean $\pm \mathrm{SD}, \mathrm{n}=10$

ns $=$ non significant at $\mathrm{P} \leq 0.05$, according to Student's t test

\section{Conclusion}

Raw seeds of $C$. occidentalis are toxic. This toxicity was manifested in albino mice by a body weight loss, decrease in serum proteins level and increase in serum ammonia level, liver enzymes (GOT and GPT) activities and
Hepato-Somatic Index. The roasting of seeds at $200^{\circ} \mathrm{C}$ for 10 min eliminated the toxicity. In addition, the boiled water used as solvent was ineffective to dissolve the toxin in the extract, which conducts to absence of toxic activity in the extract consumed. 


\section{References}

[1] Dennis, P. A. (1988). Herbal Medecine among Miskito of Eastern Nicaragua. Economic Botany, 42(1), 16-28.

[2] Gupta, M. P. (1979). Ethnopharmacognotics Observations on Panamanian Medicinal Plants. Part I. Quaterly Journal of Crude Drug Research, 17(3/4), 115-130.

[3] Nagaruja, N. (1990). A survey of Plant Crude Drugs of Rayalaseema, Andhra Pradesh, India. Journal of Ethnopharmacology, 29(2), 137-158.

[4] Raintree Nutrition (1999).Tropical plant database: Feddegoso (Cassia occidentalis).Carson City, NV 89701:Raintree Nutrtion, Inc.

[5] Dupriez, H, \& De Leener, P. (1987). Jardins et vergers d'Afrique. Terre et vie, Ed. L'Harmattan, Paris (354pp).

[6] Berhaut, J. (1975). Flore illustrée du Sénégal, Tome IV, Clairafrique Ed., Dakar, pp. 34-79.

[7] Marrero, F. E., Bulnees, G. C., \& Perez, R. M. (1998). Cassia occidentalis toxicosis in heifers. Veterinary and Human Toxicology, 40(5), 307.

[8] Haraguchi, M., Calore, E. E., Dagli, M. L., Cavaliere, M. J., Calore, N. M., Weg, R., Raspantini, P. C., \& Gorniak, S. L. (1998). Muscle atrophy induced in broiler chicks by parts of Senna occidentalis seeds. Veterinary Research Communication, 22(4), 265-271.

[9] Calore, E. E., Cavalier, M. J., Haraguchi, M., Gorniak, S. L., Dagli, M. L., Raspantini, P. C., Calore, N. M., \& Weg, R. (1998). Toxic peripheral neuropathy of chiks fed Senna occidentalis seeds. Ecotoxicology and Environmental Safety, 39(1), 27-30.

[10] Cavaliere, M. J., Calore, E. E., Haraguchi, M., Gorniak, S. L., Dagli, M. L., Raspantini, P. C., Calore, N. M., \& Weg, R. (1997). Mitochondrial myopathy in Senna occidentalis seeds fed chicken. Ecotoxicology and Environmental Safety, 37(2), 181-185.

[11] Flory, W., Spainhour, C. B., Colvin, B., \& Herbert, C. D. (1992). The toxicologic investigation of a feed grain contaminated with seeds of the plant species Cassia. Journal of Veterinary Diagnotic Investigation, 4(1), 65-69.

[12] Colvin, B. M., Harrison, L. R., Sangster, L. T., \& Gosser, H. S.(1986). Cassia occidentalis toxicosis in growing pigs. Journal of the American Veterinary Medical Association, 189(4), 423-426.

[13] Medoua, N. G., \& Mbofung, C. M. F. (2007). Kinetics studies of some physico-chemical substances during roasting and preparation of beverage made by Cassia occidentalis seeds. LWT, 40(4), 730-736.

[14] Suliman, H. B., \& Shommein A. M. (1986). Toxic effect of the roasted and unroasted beans of Cassia occidentalis in goats. Veterinary and Human Toxicology, 28(1), 6-11.

[15] Hebert, C. D., Flory, W., Seger, C., \& Blanchard, R. E. (1983) Preliminary isolation of a myodegerative toxic principle from Cassia occidentalis. American Journal of Veterinary Researh, 44(7), 1370-1374.

[16] Graziano, M. J., Flory, W., Seger, C. L., \& Hebert, C. D. (1983). Effect of a Cassia occidentalis extract in the domestic chicken (Gallus domesticus). American Journal of Veterinary Research, 44(7), 1238-1244.

[17] NIH (1996). Guide for the Care and Use of Laboratory Animals. The National Academies Press, Washington, DC, USA, $125 \mathrm{p}$.

[18] Bradford, M. M. (1976). A rapid and sensitive method for the quantitation of microgram quantities of protein utilizing the principle of protein-dye binding. Anal. Biochem, 72, 248-254.

[19] Suliman H. B., Wasfi I. A. et Adam S. E. (1982). The toxicity of Cassia occidentalis to goats. Veterinary and Human Toxicology, 24(5), 326-330. 